\title{
ZAUFANIE INSTYTUCJONALNE W KONTEKŚCIE USTAWOWEJ ZASADY ZAUFANIA JEDNOSTKI DO PAŃSTWA
}

Zaufanie jest ważną i pożądaną cechą relacji międzyludzkich. Obniża ryzyko i koszty transakcji ${ }^{1}$, a dokonywane wymiany dóbr są wyjaśniane właśnie za jego pomoca ${ }^{2}$. Sławna jest teza sformułowana przez F. Fukuyamę o związku między poziomem zaufania a rozwojem ekonomicznym ${ }^{3}$, jednocześnie coraz częściej zwraca się uwagę na kryzys zaufania, i to nawet w krajach, w których jego poziom był tradycyjnie wysoki ${ }^{4}$.

Większość prac poświęconych zaufaniu poświęcona jest zaufaniu międzyludzkiemu (interpersonalnemu). Przedmiotem artykułu będzie jednak zaufanie, o którym mówi się, że jest skierowane pod adresem instytucji, stąd zwanym pionowym, instytucjonalnym lub holistycznym ${ }^{5}$. Należy jednak zastrzec, że dla potrzeb tego tekstu przez słowo ,,instytucja” będę rozumiał organy stanowiące lub stosujące prawo ${ }^{6}$. Jest to więc bardzo zawężone znaczenie, świadomie pomijające - ze względu na roległość problematyki dyskusję tocząca się w socjologii na temat treści tego pojęcia ${ }^{7}$. Powodem przyjęcia tego ograniczenia jest rozważanie w dalszej części tekstu problematyki zaufania w kontekście ustawowej zasady zaufania, której wyrazem sa

1 B. Nooteboom, Social Capital, Institutions and Trust, http://papers.ssrn.com/sol3/papers. cfm?abstract_id =903747, s. 2.

${ }^{2}$ R. Hardin, Zaufanie, tłum. A. Gruba, Warszawa 2009, s. 44.

${ }^{3}$ F. Fukuyama, Zaufanie: kapitat spoteczny a droga do dobrobytu, Warszawa 1997.

${ }^{4}$ R. Putnam, Samotna gra w kregle. Upadek $i$ odrodzenie wspólnot lokalnych w Stanach Zjednoczonych, tłum. P. Sadura, S. Szymański, Warszawa 2008. Wzrost zaufania poprzez budowanie tzw. kapitału społecznego stał się również jednym z celów rozwoju przedstawionym w raporcie Polska 2030. Zob. http://www.polska2030.pl wyzwanie 10, s. 337 i n.

${ }^{5}$ M. Frykowski, Zaufanie spoteczne mieszkańców Łodzi, Łódź 2005, s. 13. Dwa ostatnie określenia sa charakterystyczne dla anglojęzycznej literatury przedmiotu. Zob. np. J. Hudson, Institutional Trust and Subjective Well-Being across the EU, „Kyklos” 2006, nr 1, s. 43. T. Stawecki w swojej typologii związków między relacją zaufania a porządkiem prawnym wskazuje, że tego rodzaju zaufanie stanowi przedmiot ochrony prawa i uznaną wartość prawną, idem, Prawo i zaufanie. Refleksja czasu kryzysu, w: J. Oniszczuk (red.), Normalność i kryzys. Jedność czy różnorodność. Refleksje filozoficzno-prawne i ekonomiczno-spoteczne $w$ ujęciu aksjologicznym. Część II projektu „Banki centralne wobec kryzysu ekonomicznego" - wartości, Warszawa 2010, s. 122.

${ }^{6}$ Odpowiada ono w takim zakresie temu, co N. MacCormick określa jako ,institution-agency” (idem, Institutions of Law. An Essay in Legal Theory, New York 2007, s. 35).

7 Zob. np. A. Kozak, Granice prawniczej wtadzy dyskrecjonalnej, Wrocław 2000, s. 36 i n.). 
dwa przepisy: art. 8 Kodeksu postępowania administracyjnego ${ }^{8}$ i art. $121 \S 1$ Ordynacji podatkowej ${ }^{9}$. Problematykę tę wyznaczają dwa pytania:

1) jakie znaczenie terminowi ,,zaufanie” użytemu w przywołanych przepisach można przypisać oraz czy w świetle formułowanych w literaturze przedmiotu definicji terminu ,zaufanie” zaufanie instytucjonalne jest w ogóle pojęciowo możliwe?

2) jakie środki służą osiagganiu celu, jakim jest zaufanie do organów administracji?

I. Zaufanie jest przedmiotem zainteresowania wielu nauk społecznych: socjologii, psychologii, ekonomii, by wymienić tylko niektóre. Mimo to wciąż uważa się termin ,zaufanie” za trudny do zdefiniowania. T. Hobbes pisał: „,Mieć wiarę w kogoś lub ufać komuś, lub wierzyć komuś to wszystko oznacza tę samą rzecz, a mianowicie przekonanie o prawdomówności tego człowieka" ${ }^{10}$. Dla R. Hardina „ufać komuś to znaczy wierzyć, że osobą tą kieruja dobre intencje oraz że jest zdolna do tego, czego od niej oczekujemy" ${ }^{11}$. P. Sztompka ,zaufanie” definiuje jako ,zakład podejmowany na temat niepewnych, przyszłych działań innych ludzi” ${ }^{2}$. Dla I. Pilch ,zaufanie jest relacją pomiędzy co najmniej dwoma osobami, powstającą na podstawie zależności wyniku, jaki chce osiagnąć jedna z tych osób, od zachowania się drugiej” ${ }^{13}$. M. Harding, ,zaufanie” określa, jako „optymistyczne nastawienie do wyborów dokonywanych przez innych ludzi” ${ }^{14}$.

Ujmując te charakterystyki przez pryzmat definicyjnego genus, można je z grubsza podzielić na behawioralne (P. Sztompka) i mentalne. Behawioralne ujęcie zaufania wyraża się w tym, że składa się na nie przekonanie oraz oparte na nim działanie ${ }^{15}$. Mentalne charakterystyki zaufania, które w literaturze dominuja, polegaja na charakteryzowaniu zaufania za pomoca słów wyrażających tak zwane postawy propozycjonalne (,być przekonanym, że”, „oczekiwać, że”, „sądzić, że”) ${ }^{16}$. Wreszcie, jako mieszaną można określić propozycję terminologiczną I. Pilch, dla której zaufanie jest relacją. Relacja może być wynikiem zarówno przekonania, jak i działania.

${ }^{8}$ Dz. U. Nr 30, poz. 168 z późn. zm. (dalej jako: k.p.a.).

9 Dz. U. Nr 137, poz. 926 (dalej jako: o.p.).

${ }^{10}$ T. Hobbes, Lewiatan, czyli materia, forma i wtadza państwa kościelnego $i$ świeckiego, tłum. C. Znamierowski, Warszawa 2005, s. 145. Zob. nieco odmienny przekład tego fragmentu Lewiatana w artykule G. Schwann, Zaufanie a polityka. Zatożenia teoretyczne, tłum. A. J. Schmid, „Ruch Prawniczy, Ekonomiczny i Socjologiczny" 2007, z. 2, s. 5.

${ }^{11}$ R. Hardin, op. cit., s. 25.

${ }^{12}$ P. Sztompka, Zaufanie. Fundament spoteczeństwa, Kraków 2007, s. 70. P. Sztompka ,,przekonanie" rozumie odmiennie, niż to się czyni w epistemologii, gdzie jedna z popularniejszych definicji mówi, że przekonanie to dyspozycja do działania. J. Hospers, Wprowadzenie do analizy filozoficznej, tłum. B. Chwedeńczuk, Warszawa 2001, s. 75, gdzie autor jednocześnie pokazuje słabości tej definicji. W ujęciu P. Sztompki przekonanie ma charakter bierny; jest to pasywna, ale ukierunkowana i w pewnym stopniu uzasadniona wiara, że coś się zdarzy (idem, op. cit., s. 67).

${ }^{13}$ I. Pilch, Psychologiczna analiza zaufania interpersonalnego. Podejścia teoretyczne $i$ metody badania empirycznego, w: Z. Ratajczak, W. Wosińska (red.), Zaufanie i niesprawiedliwość a społeczne funkcjonowanie człowieka, Katowice 1990, s. 18.

${ }^{14}$ M. Harding, Manifesting Trust, „Oxford Journal of Legal Studies” 2009, nr 2, s. 246.

15 P. Sztompka, op. cit., s. 71.

${ }^{16} \mathrm{Na}$ temat czasowników epistemicznych zob. M. Danielewiczowa, Wiedza i niewiedza. Studium polskich czasowników epistemicznych, Warszawa 2002. 
Ujęcie powyższych charakterystyk i definicji z punktu widzenia różnicy gatunkowej prowadzi z kolei do następujących wniosków: zaufania nie da się sprowadzić po prostu do oczekiwania (przewidywania) jakiegoś zdarzenia przyszłego, dlatego że zaufanie musi dodatkowo zawierać element korzystny dla osoby ufającej oraz zaufanie ma charakter międzyludzki.

1. Niemożność sprowadzenia zaufania do oczekiwania uwolnionego od perspektywy korzyści podmiotu oczekującego prowadzi do odróżniania polegania na kimś od zaufania ${ }^{17}$.

W sytuacji polegania na kimś występuje element przewidywania bez elementu dobrej woli, natomiast sytuacja zaufania obejmuje zarówno przewidywanie, jak i przekonanie o dobrej woli drugiej strony. Różnicę tę obrazuje następujący dylemat: Czy sąsiad I. Kanta regulujący swój zegarek na podstawie jego, legendarnie regularnego, rozkładu dnia pokładał w Kancie zaufanie, czy jedynie polegał na jego sposobie zachowania? W związku z tym, że zaufanie opiera się na dobrej woli drugiej strony, a poleganie na kimś zawiera element przewidywania zachowania drugiej strony, jednak bez jej dobrej woli, sasiad Kanta jedynie na nim polegał, ale nie można powiedzieć, że mu ufał ${ }^{18}$. Zdajemy sobie sprawę, że w języku naturalnym wyrażeniem zaufania może być stwierdzenie ,,polegam na Tobie”, jednak to okoliczności będą decydowały o tym, czy tego rodzaju powiedzenie będzie oznaczało zaufanie, czy jedynie poleganie $n a^{19}$.

2. Międzyludzki charakter zaufania prowadzi do kwestii, czy to, co jest określane mianem zaufania do organów państwa, czy szerzej, okazywanego zaufania do konkretnych osób (członkowie rodziny, przyjaciele, osoby publiczne), ról społecznych, przez grupy społeczne, instytucje i organizacje, systemy techniczne, po ogólne właściwości systemu społecznego zasługuje na miano „zaufania”. P. Sztompka twierdzi, że wszystkie te odmiany „,funkcjonuja na podstawie tej samej logiki”, czyli dają się zredukować do ludzkich działań ${ }^{20}$. Jeżeli natomiast zaufanie międzyludzkie jest czymś istotnie różnym od zaufania instytucjonalnego, to pojawia się pytanie o treść tego ostatniego wyrażenia.

Stanowisko (będę je nazywał tezą o jedności), że zaufanie instytucjonalne różni się od zaufania międzyludzkiego tylko tym, iż adresatem zaufania instytucjonalnego jedynie pozornie jest jakiś byt abstrakcyjny (rola społeczna,

${ }^{17}$ G. Graff, Etyczne aspekty zaufania, „Prakseologia” 2003, nr 143, s. 101. Można też wspomnieć, że wiązanie zaufania z korzyścią umożliwia odróżnienie treści pojęcia zaufania od treści pojęcia pewności. W przypadku pewności można mówić: „Jestem pewien, że rozstrzygnięcie będzie dla mnie niekorzystne”, podczas gdy zdanie: „Ufam, że rozstrzygnięcie będzie dla mnie niekorzystne” jest po prostu niepoprawne ze względów frazeologicznych. Być może mogłoby to stanowić kryterium odróżnienia konstytucyjnej zasady zaufania od zasady pewności prawa, które dość często są utożsamiane. Zob. np. J. Potrzeszcz, Idea prawa $w$ orzecznictwie polskiego Trybunatu Konstytucyjnego, Lublin 2007, s. 228.

${ }^{18}$ Przykład pochodzi z artykułu G. Graff, op. cit., s. 101.

19 Jako hipotezę można potraktować twierdzenie, że wypowiedź: ,polegam na Tobie” będzie oznaczało zawsze zaufanie, a ,,polegam na nim" zaufanie lub jedynie poleganie na.

${ }^{20}$ P. Sztompka, op. cit., s. 111. 
określona procedura postępowania, systemy techniczne), a tak naprawdę za nimi ,stoją zawsze jacyś ludzie” ${ }^{21}$, natrafia jednak na trudności. Są one głównie spowodowane przyjmowanymi definicjami terminu ,zaufanie”. Na przykład koncepcja zaufania jako ,zawierania się korzyści” ${ }^{22}$ polega na tym, że podmiot ufający ma podstawy, by ufać innemu podmiotowi wówczas, gdy interesy podmiotu, który został obdarzony zaufaniem, zawieraja się $\mathrm{w}$ interesach podmiotu ufającego. ,Zawieranie się” oznacza, że podmiot obdarzony zaufaniem uważa interesy podmiotu ufającego za swoje tylko dlatego, że są właśnie jego interesami. Możliwe sa trzy tego rodzaju sytuacje: obu stronom zależy na utrzymaniu cennej dla nich relacji, obie strony pozostaja w związku uczuciowym, osoba obdarzona zaufaniem ceni swą reputację, więc w jej interesie leży zachowanie zgodne oczekiwaniami ufającego ${ }^{23}$.

Trudno doszukiwać się dwóch pierwszych rodzajów sytuacji w wypadku relacji organy władzy-jednostka. Nic więc dziwnego, że twierdzi się, iż „,stosunki łączące obywateli z władzą nie są takimi, na których zaufanie mogłoby się oprzeć”, co najwyżej opieraja sie na ,indukcyjnym przekonaniu lub przyzwoleniu" ${ }^{24}$, a postulaty większej ufności zapoznaja problem wiarygodności tego, w kim taką ufność można złożyć ${ }^{25}$.

Jedynie definicja zaufania jako zakładu jest do pewnego stopnia odporna na powyższe zarzuty ${ }^{26}$. Do pewnego stopnia, gdyż konstytucyjna zasada zaufania już w swojej nazwie (,zasada zaufania jednostki do państwa i stanowionego przez nie prawa") wymienia adresatów zaufania: państwo i prawo. Definicja zaufania jako zakładu rodzi problemy w przypadku właśnie organów państwa. Na czym bowiem miałoby polegać działanie będące wyrazem zaufania w odniesieniu do na przykład Prezesa Rady Ministrów? ${ }^{27}$ Mogłoby ono mieć miejsce $\mathrm{w}$ przypadku, gdyby osoba pełniąca ten urząd wzywała obywateli do jakiejś aktywności, jednak tego rodzaju apele to wycinek działalności tego urzędu.

Ponadto zaufaniu zawsze towarzyszy ryzyko utraty jakiegoś dobra, właśnie wskutek aktu zaufania ${ }^{28}$. W wypadku deklarowanego zaufania do instytucji, takiej jak na przykład Sejm, czy szerzej: organów stanowiących prawo, trudno jednak przedstawić, jakiego rodzaju ryzyko miałaby ponosić osoba deklarująca takie zaufanie. Byłoby to ewentualnie możliwe, gdyby adresatami pytania badawczego byli na przykład przedsiębiorcy, którzy kierując się deklaracjami politycznymi partii rządzącej, podjęli określone działania wiążące się z poniesieniem pewnych kosztów i ryzykiem straty finansowej, gdyby deklaracje ten nie zostały zrealizowane. Przeprowadzane w Polsce badania zaufania maja

${ }^{21}$ Ibidem, s. 104.

${ }^{22}$ R. Hardin, op. cit., s. 33.

${ }^{23}$ Ibidem, s. 27.

${ }^{24}$ Ibidem, s. 177.

${ }^{25}$ Ibidem, s. 35.

${ }^{26}$ Zauważa to również E. Tarkowska w swojej recenzji przywoływanej tutaj książki P. Sztompki: eadem, Co to takiego: zaufanie, „Etyka” 2007, nr 40, s. 174.

${ }^{27}$ Zwraca na to uwagę również R. Hardin, op. cit., s. 42.

${ }^{28}$ P. Sztompka, op. cit., s. 82; J. Hudson, op. cit., s. 46. 
jednak charakter ankietowy i nie ograniczaja swego przedmiotu badania do wybranych pod tym kątem grup społecznych ${ }^{29}$.

Jeżeli jednak odróżnimy konstytucyjną zasadę zaufania od ustawowej zasady zaufania wyrażonej $\mathrm{w}$ przepisach Ordynacji podatkowej i Kodeksu postępowania administracyjnego, to naturalnie adresatami tej ostatniej sa organy administracji, chociaż w tym miejscu lepiej je nazywać organami stosującymi prawo. W odniesieniu do nich definicja ,zaufania” jako zakładu jest znacznie bardziej adekwatna, ponieważ działaniem, z jakim wiąże się ryzyko, jest na przykład wniesienie skargi.

W przypadku zaufania do prawa działanie może polegać na wykorzystywaniu przewidzianych przez prawo sposobów rozwiązywania konfliktów. Powstaje jednak również problem adresata takiego zaufania. Mówiąc obrazowo, kto miałby być „,twarzą” prawa: sędziowie, adwokaci, legislatorzy? A może jeszcze ktoś inny? Zwolennik tezy o jedności odpowiedziałby, że postawienie takiego pytania stanowi argument wspierający jego tezę. W przypadku jednak podjęcia badań empirycznych badacz chcący zbadać zaufanie do prawa nie będzie mógł poprzestać na ogólnym pytaniu: „,czy ufasz prawu?”, ponieważ wiele osób mogłoby mieć uzasadnione kłopoty z uznaniem tego pytania za sensowne. Badacz będzie więc musiał sprecyzować pytania, ponieważ można ufać sędziom i nie ufać adwokatom. A nawet jeżeli dana osoba deklarowałaby zaufanie i do sędziów, i do adwokatów, to „suma” tego zaufania nie będzie oznaczała zaufania do prawa.

Nasuwa się więc wniosek, że zaufanie interpersonalne różni się od zaufania do organów władzy tym, iż to pierwsze zawiera analitycznie - by tak rzec element ryzyka. W przypadku zaufania do organów władzy ryzyko ma charakter przygodny i występuje jedynie w sytuacji uruchomienia stosownej procedury przed organami stosującymi prawo. Element ryzyka jest natomiast w zasadzie nieobecny w przypadku stosunku jednostki i organów stanowiących prawo. Teza o jedności wydaje się więc uzasadniona w odniesieniu do organów stosujących prawo.

Pozostaje jednak jeszcze jedna ważna sprawa. Przytoczona wyżej definicja zaufania jako zakładu zapoznaje odróżnienie zaufania i polegania na kimś. Wszystkie przytaczane przez P. Sztompkę definicje, które mają oddawać to samo znaczenie terminu ,zaufanie”, zawieraja jakieś odniesienie do elementu dobrej woli adresata zaufania. Element ten bywa różnie nazywany: korzystnymi intencjami ${ }^{30}$, wzięciem pod uwagę interesów drugiego partnera $\mathrm{w}$ toku wymiany $^{31}$, ufnością, że rezultaty działań drugiej strony będą właściwe z punktu widzenia osoby ufającej ${ }^{32}$. Jest on jednak, co zaskakujące, nieobecny

\footnotetext{
${ }^{29}$ Wśród osób ankietowanych wyróżnia się naturalnie grupy cechujące się określonym poziomem zaufania, np. osoby z wyższym wykształceniem, wysoką pozycją społeczno-zawodową są bardziej ufne. B. Wciórka, Spoteczeństwo obywatelskie 1998-2004, Warszawa 2004, s. 33. To jednak nie rozwiązuje problemu istnienia elementu ryzyka.

${ }^{30}$ J. Dunn, Trust and Political Agency, w: D. Gambetta (red.), Trust: Making and Breaking Cooperative Relations, Oxford 1988, s. 74, cyt. za: P. Sztompka, op. cit., s. 70 (przyp. 7).

${ }^{31}$ N. Lin, Social Capital: A Theory of Social Structure and Action, Cambridge 1989, s. 147, cyt. za: P. Sztompka, op. cit.

${ }^{32}$ B. Misztal, Trust in Modern Societies: The Search for the Bases of Social Order, Cambridge 1996, s. 9-10, cyt. za: P. Sztompka, op. cit.
} 
w samej definicji zaufania jako zakładu, podczas gdy stanowi on jeden z konstytutywnych elementów zaufania. To powoduje, że definicja P. Sztompki odnosi się właściwie do polegania na, a nie zaufania. Włączenie tego elementu do treści pojęcia zaufania jest konieczne, ponieważ, jak niżej zobaczymy, oczekiwania, jakie żywić może jednostka pod adresem organów administracji dadzą się opisać za pomocą tego elementu. Dalej będziemy go nazywać elementem korzyści podmiotu ufającego. Treścią aktu zaufania są oczekiwania pewnego rodzaju zachowania. Jakie to oczekiwania?

3. W celu odpowiedzi na to pytanie skorzystamy ze skali wiarygodności sporządzonej przez P. Sztompkę, na której znajdują się oczekiwania ułożone od najmniej do najbardziej wymagających, a następnie zastanowimy się, które $\mathrm{z}$ nich są oczekiwaniami, które jednostka może ${ }^{33}$ żywić, biorąc pod uwagę regulacje Kodeksu i Ordynacji. Oczekiwania mogą dotyczyćc ${ }^{34}$ :

a) instrumentalnych właściwości działań podejmowanych przez adresatów zaufania; tworzą one skalę uporządkowaną od najmniej do najbardziej ryzykownych oczekiwań: regularność (ciagłość, trwałość), uwaga (koncentracja adresata zaufania na osobie ufającej, na przykład grzesznik w konfesjonale), zasadność podejmowanych działań przez adresata zaufania $\mathrm{w}$ tym sensie, że dysponuje on dobrym uzasadnieniem, skuteczność (kompetencja w znaczeniu posiadania odpowiednich umiejętności) - OI,

b) moralnych właściwości działań: odpowiedzialności moralnej, życzliwości, prawdomówności, szczerości, lojalności, sprawiedliwości i bezstronności-OM,

c) przedłożenia przez druga osobę interesu innych nad własnym interesem; przykładem takich oczekiwań sa: bezinteresowność, współczucie, działania przedstawicielskie - OA.

Niewątpliwie można mówić o tym, że każdy potencjalny wnioskodawca lub skarżący żywi OI. Kategoria regularności jest bowiem pochodną obowiązywania norm abstrakcyjnych i generalnych. Kategorii uwagi da się przypisać obowiązek zapewnienia stronie czynnego udziału w postępowaniu (art. 10 k.p.a.) i wynikający instrumentalnie $\mathrm{z}$ niego obowiązek wysłuchania i rozpatrzenia jego wniosków. Zasadność podejmowanych działań znajduje swój odpowiednik na gruncie normatywnym $\mathrm{w}$ obowiązku wyjaśniania zasadności przesłanek, którymi organy kierują się przy załatwieniu sprawy decyzji stosowania prawa (art. 11 k.p.a. i art. 124 o.p.). Wreszcie kategorii skuteczności odpowiada na przykład zasada szybkości postępowania (art. 12 k.p.a. i art. 125 o.p.).

Nieco inaczej sprawa wygląda z OM i OA. Oczekiwanie zachowań moralnych może być skierowane jedynie do człowieka, z tej prostej racji, że zachowań moralnych można wymagać jedynie od niego, jako istoty rozumnej i wolnej. Zwolennik tezy o jedności wskazałby zapewne, że przecież każdy organ działa przez konkretne osoby, którym przysługuje przymiot człowieczeństwa. Nasuwają się w tym miejscu dwie kwestie, z których jedna zdaje się implikować druga.

\footnotetext{
${ }^{33}$ Słowo „może” jest użyte tutaj w znaczeniu tetycznym. Zob. Z. Ziembiński, Logika praktyczna, Warszawa 1976, s. 124.

${ }^{34}$ P. Sztompka, op. cit., s. 122-128.
} 
Przede wszystkim chodzi o socjologiczno-epistemologiczną możliwość dostrzeżenia konkretnego człowieka stojącego za decyzja stosowania prawa, a to pociaga za sobą zasadność żywienia przynajmniej niektórych OM.

Owo „dostrzeżenie człowieka” oznacza, że jednostka wnosząca swoją sprawę jest $\mathrm{w}$ stanie podstawić pod nazwę organu administracji indywidualnej nazwę lub kilka nazw indywidualnych osób mających wydać decyzję lub przynajmniej jakąś deskrypcję, na przykład ,najbardziej rzetelny pracownik urzędu skarbowego w X" ${ }^{35}$. Możliwość ta zależy oczywiście od tego, czy postępowanie zostało wszczęte, na jakim znajduje się etapie, ale również od rodzaju postępowania. $\mathrm{Z}$ natury rzeczy nie jest to możliwe przed wszczęciem postępowania przez stronę. Po wszczęciu postępowania jest to możliwe również w dość ograniczonym stopniu, ponieważ Kodeks postępowania administracyjnego nie przewiduje przeprowadzania rozprawy w każdym przypadku (art. 89 § 1 i $§ 2$ k.p.a.), $\mathrm{w}$ postępowaniu podatkowym zaś rozprawa jest przeprowadzana jedynie w postępowaniu odwoławczym w sytuacjach określonych przez art. 200a o.p. Naturalnie można twierdzić, że moralne własności działań mogą również odnosić się do działań, których przejawem sa pisma, jednak sądzimy, że w takim przypadku OM będa znacznie słabsze niż w sytuacji bezpośredniego kontaktu $\mathrm{z}$ osobą pełniąca funkcję organu stosującego prawo. Z tą ostatnią sytuacją mamy natomiast do czynienia na przykład w postępowaniu sądowym, w którym postawa sędziego, sposób prowadzenia przez niego rozprawy może stanowić podstawę nie tylko przewidywań co do sposobu rozstrzygnięcia, ale również pewnego stopnia zaufania (lub jego braku).

Z listy wskazanych moralnych własności działań, których można oczekiwać od drugiej strony, w omawianym przez nas kontekście postępowania administracyjnego i podatkowego zdecydowanie należy wykluczyć cechę lojalności, jako zachowania wręcz zabronionego podmiotom występującym w roli organów stosujaccych prawo. Temu celowi mają między innymi służyć przepisy o wyłączeniu pracownika oraz organu.

Naruszenie wymogu prawdomówności, co mogłoby polegać na nieprawdziwej informacji na temat treści przepisów prawa, byłoby naruszeniem nie tylko normy moralnej, ale i prawnej w postaci na przykład art. 9 k.p.a.

Z kolei wymóg bezstronności w postępowaniu administracyjnym domaga się objaśnienia w świetle wskazywanych odrębności sądowego i pozasądowego typu stosowania prawa ${ }^{36}$. Jedną $\mathrm{z}$ nich jest bowiem fakt bezstronności sądu i jego brak zainteresowania w treści decyzji ${ }^{37}$. Z kolei w odniesieniu do pozasądowego trybu stosowania prawa podkreśla się rolę konieczności realizacji norm zadaniowych przez organy administracji, które są zobowiązane urzeczywistniać

\footnotetext{
${ }^{35}$ Pojęciem deskrypcji posługuję się na oznaczenie kategorii nazwowej, czyli w takim znaczeniu, w jakim posługiwał się nim B. Russell; idem, Problemy filozofii, tłum. W. Sady, Warszawa 1995, s. 60, oraz hasło Deskrypcja, w: Mała encyklopedia logiki, Wrocław-Warszawa-Kraków 1970, s. 48. Dla opisanej wyżej sytuacji nie ma znaczenia, czy możliwość dotyczyć będzie deskrypcji określonej, jak wyżej, czy nieokreślonej, jak np. jeden z bardziej rzetelnych pracowników Urzędu Skarbowego $w$ X.

${ }^{36}$ Na temat tych odrębności zob. np. L. Leszczyński, Zagadnienia teorii stosowania prawa. Doktryna i tezy orzecznictwa, Kraków 2001, s. 19-28; idem, Podejmowanie decyzji prawnych. Tworzenie i stosowanie prawa, Zamość 2003, rozdz. II i III.

${ }^{37}$ L. Leszczyński, Zagadnienia..., s. 21.
} 
określoną wizję życia społecznego ${ }^{38}$. W pewnym sensie organ administracji jest zainteresowany treścią decyzji, stąd można by sądzić, że nie jest bezstronny. Sądzimy jednak, że należy odróżniać pewien ,rdzeń” bezstronności wyznaczany zarówno przez wspomniane przepisy postępowania administracyjnego o wyłączeniu pracownika i organu, jak i przepisy proceduralne (karne i cywilne) o wyłączeniu sędziego. Twierdzenia o realizacji określonej polityki przez organy administracji lokują się właśnie poza owym „,rdzeniem” ${ }^{39}$. W dalszym ciągu bezstronność wyznaczoną przez przepisy proceduralne będę nazywał bezstronnościa pierwszego stopnia, zaś bezstronność jako brak zainteresowania w treści decyzji - bezstronnością drugiego stopnia.

Oczekiwanie życzliwości znajduje swoje normatywne podstawy w art. 12 Europejskiego kodeksu dobrej administracji oraz art. 24 ust. 2 pkt 5 ustawy z 21 listopada 2008 r. o pracownikach samorządowych ${ }^{40}$. Zagadnienie życzliwości w kontekście organu stosującego prawo wymaga jednak kilku słów komentarza.

W historii myśli etycznej życzliwość jest przedstawiana jako jedna z cnót. D. Hume, który umieszczał ją wśród cnót naturalnych, wiązał ją z miłością rozumianą jako pragnieniem szczęścia drugiej osoby ${ }^{41}$. C. Znamierowski określał ją jako przychylność, która raduje się cudzą radością ${ }^{42}$ i w swej koncepcji powszechnej życzliwości, podając brzmienie naczelnej normy moralnej, pisał między innymi: ,[człowiek powszechnie życzliwy - dop. M.W.] powinien powstrzymywać się od wszelkiego działania, które nie pozwala powstawać cudzym radościom" ${ }^{43}$. Łatwo jest konstruować przykładowe sytuacje, w których podmiot stosujący prawo, pragnąc działać zgodnie z nim, musi naruszyć tego rodzaju normę moralną (na przykład wydając decyzję nakazująca rozbiórkę domu wzniesionego bez pozwolenia budowlanego). Stąd zasadne będzie twierdzenie o często zachodzącym konflikcie pomiędzy tak rozumiana życzliwością a dyrektywą podejmowania działania na podstawie prawa ${ }^{44}$. W tej sytuacji postulat życzliwości znajdujący się w cytowanej ustawie o pracownikach samorządowych należy rozumieć skromniej: jako nakaz uprzejmości stanowiący element zasad dobrego wychowania ${ }^{45}$. Nawet jednak tak rozumiany

${ }^{38}$ Idem, Podejmowanie..., s. 106. Zob. również B. Wojciechowski, Dyskrecjonalność sędziowska. Studium teoretycznoprawne, Torun 2004, s. 99 w odniesieniu do decyzji o charakterze dyskrecjonalnym podejmowanych przez sądy i organy administracji.

${ }^{39}$ Potwierdzeniem tego może być uchylenie art. 27a k.p.a., ponieważ jego wykładnia dokonana przez TK w uchwale z 23 czerwca $1993 \mathrm{r}$. dotycząca ustalenia powszechnie obowiązującej wykładni art. 27a k.p.a. (Dz. U. Nr 59, poz. 278), uniemożliwiała wykonywanie przez gminy zadań własnych $\mathrm{w}$ formie decyzji w wielu dziedzinach, m.in. w zakresie gospodarki gruntami czy lokalami stanowiącymi własność gminy. M. Jaśkowska, A. Wróbel, Kodeks postępowania..., s. 242.

${ }^{40}$ Dz. U. Nr 223, poz. 1458 z późn. zm.

${ }^{41}$ D. Hume, Traktat o naturze ludzkiej, tłum. C. Znamierowski, Warszawa 2005, s. 443.

${ }^{42}$ C. Znamierowski, Rozważania wstępne do nauki o moralności i prawie, Warszawa 1964, s. 32.

${ }^{43}$ Ibidem, s. 50.

${ }^{44}$ Z. Bankowski, kreśląc różnice pomiędzy działaniem na podstawie prawa a działaniem na podstawie miłości, zauważa, że działanie na podstawie miłości jest arbitralne, nieprzewidywalne i opiera się na zupełnie innych racjach niż działanie na podstawie reguł. Z. Bańkowski, Law, Love and Legality, „International Journal for the Semiotics of Law” 14, 2001, nr 2, s. 200.

${ }^{45}$ Można mieć wątpliwości, czy pozytywizacja norm obyczajowych jest rzeczywiście potrzebna z punktu widzenia celów, jakie przed nią się stawia. 
postulat nie zawsze może zostać spełniony ze względu na pisemność postępowania i wiążący się z nim sposób postrzegania podmiotu skarżącego przez osoby działające jako organ administracji. Można go opisać, wykorzystując pojęcie alienacji rozumiane jako depersonalizacja, brak bezpośredniości i spontaniczności stosunków międzyludzkich ${ }^{46}$. Opisuje ono również sytuacje, w której kontakt urzędnika i petenta ma charakter spotkania „twarzą w twarz”, jednak zdecydowanie bardziej jest adekwatne do sytuacji, w której jednostka jest jedynie jednym $\mathrm{z}$ wielu nazwisk $\mathrm{w}$ długim ciągu innych spraw. Biorąc powyższe pod uwagę, oczekiwanie życzliwości, jakkolwiek uzasadnione, biorąc pod uwagę treść przepisów, jest znacznie mniej uzasadnione, biorąc pod uwagę „,naturę” stosunków łączących organ administracji oraz jednostkę.

Odniesienie sytuacji, w której oczekiwania dotyczą przedłożenia interesu cudzego nad własny, do relacji jednostki i organów podatkowych lub innych organów administracyjnych nie jest łatwe. Należałoby przede wszystkim uznać, że organy maja jakiekolwiek interesy, a następnie je poświęcają na rzecz jednostki. Wspominałem już, że wskazując na różnice pomiędzy sądowym a administracyjnym modelem stosowania prawa, zwraca się uwagę na realizację przez organy administracji określonej polityki ${ }^{47}$, jednak uważam, iż nie wystarcza to do uznania, że organy administracji maja jakieś interesy. Nawet gdyby jednak zgodzić się na taką terminologię, to wciąż bezzasadne byłoby tego rodzaju oczekiwanie jednostki pod adresem organu administracji. Sytuacja wyjątkową również pod tym względem jest możliwość umorzenia zaległości podatkowych przez organ podatkowy w przypadkach uzasadnionych ważnym interesem podatnika lub interesem publicznym (art. 67 a $§ 1$ pkt 3 o.p.). Jeżeli traktować organ podatkowy jako podmiot reprezentujący interesy Skarbu Państwa, to są sytuacje, w których interes podatnika może przeważyć interes Skarbu Państwa. Problematyczność jednak mówienia o uzasadnionych oczekiwaniach $\mathrm{w}$ tej sytuacji polega na tym, że decyzja organu podatkowego jest podejmowana $\mathrm{w}$ ramach uznania administracyjnego, co zdaniem orzecznictwa znaczy, że nawet w wypadku, gdy organ podatkowy stwierdzi istnienie ważnego interesu podatnika lub interesu publicznego $\mathrm{w}$ umorzeniu zaległości podatkowej może - działając w ramach uznania administracyjnego - odmówić zastosowania ulgi podatkowej.

Powyższe uwagi upoważniają do sformułowania następujących twierdzeń. W myśl definicji zaufania jako zakładu zaufanie instytucjonalne jest pojęciowo możliwe, ale definicja ta nie uwzględnia elementu korzystnego dla podmiotu ufającego. Przyjęcie definicji zaufania jako zakładu bez elementu korzystnego dla podmiotu ufającego prowadzi do uznania, że termin ,zaufanie” użyty $\mathrm{w}$ art. $121 \S 1$ o.p. i art. 8 k.p.a. oznacza jedynie sytuacje polegania na organie administracji, a nie zaufania do niego. Jeżeli natomiast definicję tę uzupełnić o ten element, to porównanie rodzajów oczekiwań podmiotu ufającego w świetle zasad ogólnych Kodeksu postępowania administracyjnego

\footnotetext{
${ }^{46}$ Syntetycznie na temat pojęcia alienacji zob. J. Szacki, Alienacja, w: Encyklopedia socjologii. Suplement, Warszawa 2005, s. 14-16.

${ }^{47}$ L. Leszczyński, Zagadnienia teorii stosowania prawa. Doktryna i tezy orzecznictwa, Kraków 2001, s. 23.
} 
i Ordynacji podatkowej uzasadnia wniosek, że zaufanie jednostki do stosujących prawo organów administracji może mieć wymiar instrumentalny oraz moralny, w znaczeniu podanym wyżej.

II. Ustaliwszy, w jakim znaczeniu ustawodawca posługuje się terminem „zaufanie” w przepisach Kodeksu postępowania administracyjnego i Ordynacji podatkowej, należy krótko poruszyć sprawę środków, za pomoca których zaufanie jednostek do organów administracji może być budowane. Zasada zaufania (tak jak jest sformułowana w przepisach k.p.a. i o.p.) jest skierowana do organów administracji, co oznacza, że są one adresatami nakazu określonego postępowania. Stanowi ona normę programowa, co nie oznacza jednak jej deklaratywnego charakteru ${ }^{48}$. Norma programowa to taka, która nakazuje realizację pewnego celu, nie wskazując jednocześnie sposobów jego urzeczywistnienia. Uzasadnienie normatywnego charakteru normy programowej dokonywane jest przez rekonstrukcję schematu wnioskowania, w którym norma programowa stanowi jedną z dwóch przesłanek. Na przykładzie zasady zaufania wnioskowanie to będzie wyglądało następująco:

1. Podmiotowi P nakazane jest „pogłębianie”, „budzenie” 49 zaufania jednostek do organów państwa oraz stanowionego przez nie prawa,

2. Zachowanie Z jest środkiem „pogłębiania”, „,budzenia” zaufania jednostek do organów państwa, a zatem

Podmiotowi $\mathrm{Z}$ nakazane jest zachowanie $\mathrm{Z}$ i odpowiednio zakazane zachowanie nie-Z.

Naturalnie rodzi się pytanie, jakie zachowanie można podstawić pod zmienną Z. Do zbioru zachowań zakazanych z wewnętrznego (,prawnego”) punktu widzenia będą należały wszelkie naruszenia zasady zaufania stwierdzane w toku sądowej kontroli administracji. Orzecznictwo dostarcza bardzo wielu przykładów zastosowania zasady zaufania do organów podatkowych ${ }^{50}$. Niewiele jest jednak takich, w których zasada zaufania stanowi samoistna podstawę uchylenia aktu administracyjnego i nie pełni roli jedynie wzmacniającej („dopełnieniowej”) argumentację sądu ${ }^{51}$. Z punktu widzenia niniejszego artykułu najbardziej interesujące sa te orzeczenia, które umożliwiaja przypisanie zasadzie zaufania autonomicznej treści, to znaczy takiej, która nie byłaby redukowalna do innych przepisów szczegółowych k.p.a. oraz o.p. ${ }^{52}$

\footnotetext{
${ }^{48}$ Tezę taką uzasadniają przekonująco, wskazując jednocześnie na jej słabe punkty, A. Grabowski, T. Gizbert-Studnicki, Normy programowe $w$ konstytucji, w: J. Trzciński (red.), Charakter $i$ struktura norm konstytucji, Warszawa 1997, s. 98. Charakterystykę normy programowej przedstawiam za cytowanym tekstem. W uproszczony sposób normatywność zasady zaufania, odwołując się jedynie do faktu wynikania z konstytucyjnej zasady demokratycznego państwa prawnego oraz faktu bycia „,bezpośrednim i jasno sformułowanym elementem polskiego systemu prawa”, przedstawia A. Domańska, Zasada zaufania obywatela do państwa i stanowionego przezeń prawa, „Studia Prawno-Ekonomiczne” t. 57,1998 , s. 20 .

49 Są to czasowniki pochodzące odpowiednio z art. 8 k.p.a. i art. $121 \S 1$ o.p.

${ }^{50}$ H. Dzwonkowski (red.), Ordynacja podatkowa. Rok 2008. Komentarz, Warszawa 2008, s. 649.

${ }^{51} \mathrm{Na}$ temat tej i innych ról pełnionych przez zasady prawa zob. A. Kalisz-Prakopik, L. Leszczyński, Zasady prawa $w$ stosowaniu prawa wspólnotowego, „Europejski Przegląd Sądowy” 2005, nr 1, s. 24.

${ }^{52}$ Do rzadkości w tym kontekście należą orzeczenia kwestionujące normatywny charakter tego przepisu. Przykładem może być wyrok NSA z 20 lutego 2008 r. (I FSK 409/07) opublikowany
} 
Należy tutaj wskazać: niezmienność dokonywanej wykładni, bezstronność pierwszego stopnia ${ }^{53}$, rozstrzyganie wątpliwości na rzecz podatnika oraz równe traktowanie stron.

Trudno jednak nie dostrzec, że tego rodzaju zachowania nie stanowia warunku wystarczającego do realizacji celu w postaci zaufania. Zaufanie jako cel wyznaczony organom administracji jest stanem rozłożonym w czasie, a zatem jego poziom może się zmieniać. Implikuje to również niemożność sformułowania pełnego katalogu środków zmierzających do tak nakreślonego celu. Można sobie bowiem wyobrazić sytuację, w której żadna decyzja administracyjna nie zostanie wzruszona i w której organy administracji będa pracować w sposób bezbłędny w świetle kryteriów nie tylko określonych w k.p.a. i o.p., ale również w cytowanym Europejskim kodeksie dobrej administracji. Pomocą w wymienieniu większej liczby środków może służyć dorobek socjologiczny, dlatego że druga przesłanka ma wszak charakter empiryczny. Warto więc przytoczyć model stawania się kultury zaufania opracowany przez P. Sztompkę. Model ten składa się z trzech zasadniczych elementów ${ }^{54}$ :

a) odziedziczonej tradycji historycznej, czyli określenia, czy w danej społeczności dominuje kultura zaufania, czy nieufności,

b) warunków makrospołecznych w postaci:

- spójności normatywnej, czyli obowiązywaniu w społeczności takich norm społecznych, jak: prawo, moralność, zwyczaj,

- trwałości porządku społecznego, co nie wyklucza możliwości i potrzeby zmiany społecznej, pod warunkiem jej stopniowego i powolnego rytmu i stałego kierunku,

- przejrzystości organizacji społecznej, czyli dostępności informacji na temat funkcjonowania grup, stowarzyszeń, organizacji i ustrojów politycznych,

- swojskości (familiarności) otoczenia - na pojęcia otoczenia składają się zarówno naturalne (na przykład krajobraz i ukształtowanie terenu) jak i technologiczne czy cywilizacyjne (na przykład reguły kulturowe, jakimi ludzie się kierują),

- odpowiedzialności innych ludzi i instytucji, co ma oznaczać istnienie takich instancji, do których można się zwrócić w przypadku naruszenia przez inne podmioty norm społecznych lub zaciągniętych zobowiązań.

w Centralnej Bazie Orzeczeń Sądów Administracyjnych, w którego uzasadnieniu znajdujemy następujący fragment: ,,norma z 121 o.p. ma charakter zasady ogólnej, którą winny się kierować organy podatkowe prowadzące postępowanie podatkowe i nie ma charakteru samoistnego, lecz jest realizowana przez istniejące instytucje, które ją konkretyzuja" (orzeczenia.nsa.gov.pl/doc/D831D9011F).

${ }^{53} \mathrm{~W}$ przypadku sądowego stosowania prawa bezstronność drugiego stopnia również jest środkiem realizacji zaufania. Gdyby zaś porównać sądowy i administracyjny model stosowania prawa pod kątem właśnie realizacji zaufania, to można dojść do dwojakiego wniosku. Z jednej strony, patrząc czysto ilościowo, wymóg spełnienia dwóch obowiązków, czyli bezstronności I i II stopnia, jest, teoretycznie rzecz biorąc, trudniejszy, niż tylko jednego. $\mathrm{W}$ tym więc sensie zaufanie trudniej osiagnnąć. $\mathrm{Z}$ drugiej jednak strony (nazwę ja ,jakościowa") spełnienie dwóch obowiązków jest silniejszą gwarancją osiagnięcia zaufania niż tylko jednego - bezstronności I stopnia.

${ }^{54}$ P. Sztompka, Zaufanie..., s. 272-293. Warunki te, podobnie jak każde inne, sa naturalnie „obciążone” trudnościami związanymi z naturą rzeczywistości społecznej i możliwością sformułowania praw przyczynowych, które uzasadniłyby taki model. Zwracają na to uwagę, A. Grabowski, T. Gizbert-Studnicki, op. cit., s. 100. 
c) wyposażenia podmiotów zarówno w cechy osobowościowe (na przykład aktywizm, optymizm), jak i kapitał zbiorowy (na przykład mnogość pełnionych ról społecznych, władza, pewność zatrudnienia).

Widać, że jeżeli model jest adekwatny, to „prawne” środki pogłębiania zaufania do prawa stanowią jeden $\mathrm{z}$ wielu warunków, jakie muszą zajść, by można było mówić o osiągnięciu celu, jakim jest zaufanie instytucjonalne. Niektóre z pozostałych czynników pozostaja w ogóle poza możliwościami prawodawcy (tradycja, swojskość otoczenia, cechy osobowościowe).

$\mathrm{Na}$ zakończenie warto zauważyć, że problematyka zaufania w relacjach $\mathrm{z}$ organami administracji obejmuje również inne, nieporuszone $\mathrm{w}$ artykule kwestie. Takim zagadnieniem jest kierunkowość zaufania. Zakresem normowania ustawowej zasady zaufania jest ,pogłębianie” i „budzenie” zaufania jednostek pod adresem organów administracji. Adresatem zaufania maja więc być te ostatnie podmioty. Z punktu widzenia jednostek równie ważne może być jednak to, aby i one mogły być adresatem zaufania, a podmiotem ufającym były organy administracji. Niejednokrotnie postawa nieufności organów administracji wobec jednostek stanowi konsekwencję takich, a nie innych uregulowań prawnych. Z tego punktu widzenia na uwagę zasługuje projekt ustawy z 25 lutego 2011 r. o ograniczaniu barier administracyjnych dla obywateli i przedsiębiorców ${ }^{55}$, który w wielu miejscach obowiązek złożenia określonego zaświadczenia zastępuje możliwością dokonania przez jednostkę wyboru pomiędzy złożeniem zaświadczenia a złożeniem oświadczenia ${ }^{56}$. Jednocześnie istnieje jednak chyba nieprzekraczalna granica ograniczania nieufności organów do obywateli wyznaczona przez normę nakazująca działania zgodnie z prawem. Przejawem tego może być cytat z postanowienia Wojewódzkiego Sąu Administracyjnego w Olsztynie, dotyczącego przyznania prawa pomocy: „Skarżąca nie może oczekiwać, że przy orzekaniu o przyznaniu prawa pomocy, referendarz sądowy poprzestanie na jej oświadczeniach, iż nie posiada ona jakichkolwiek środków i nie posiada majątku, oceniając je w dodatku z pominięciem treści innych dokumentów zgromadzonych w sprawie" ${ }^{57}$.

Inną interesującą kwestia jest normatywność zaufania instytucjonalnego. Nie chodzi w tym wypadku o to, czy ustawowa zasada zaufania ma charakter dyrektywalny, to bowiem, że nią jest, wykazaliśmy wyżej, ale o analogiczny problem jak w wypadku pytania o normatywność w filozofii moralności, gdzie oznacza ono pytanie o racje, dla których dany podmiot w obliczu wyboru powinien wybrać drogę postępowania moralnego. Mówiąc kolokwialnie, dlaczego nie oszukiwać, jeżeli nikt o tym nie wie, a jest to opłacalne? Podobnie można skonstruować pytanie o normatywność w kontekście zaufania insty-

55 Druk sejmowy nr 3656.

${ }^{56}$ Zob. np. art. 16 cytowanego projektu ustawy, zastępujący dotychczasowy zapis art. 8 ust. 1a ustawy z 13 września 1996 o utrzymaniu czystości i porządku w gminach (Dz. U. Nr 236, poz. 2008) nakładający na przedsiębiorcę ubiegającego się o zezwolenie na prowadzenie działalności, o której mowa w art. 7 ust. 1, obowiązek dołączenia zaświadczenia o braku zaległości podatkowych i zaległości w płaceniu składek na ubezpieczenie zdrowotne lub społeczne zapisem, że przedsiębiorca taki jest obowiązany przedłożyć zaświadczenie lub oświadczenie.

${ }^{57}$ Postanowienie Wojewódzkiego Sądu Administracyjnego w Olsztynie z 12 maja 2010 r. (sygn. I SA/Ol 107/10 - niepubl.). 
tucjonalnego: dlaczego jako jednostka powinienem ufać organom administracji? Czy zaufanie, jakim obdarza jednostka organy administracji jest $\mathrm{z}$ jej punktu widzenia korzystne (racjonalne)? ${ }^{58}$ Wśród formułowanych odpowiedzi można znaleźć takie, które wskazują na zmniejszenie kosztów rządzenia czy dostęp do zasobów, jakimi dysponuja obywatele ${ }^{59}$, jednak z pewnością nie wyczerpują one problematyki.

Zagadnienia kierunkowości zaufania instytucjonalnego oraz jego normatywności zdają się obiecującymi kierunkami analizy, do której problemy poruszane w niniejszym artykule stanowią konieczne wprowadzenie.

dr Maciej Wojciechowski

Uniwersytet Gdański

maciejw@gnu.univ.gda.pl

\title{
INSTITUTIONAL TRUST IN THE PERSPECTIVE OF THE PRINCIPLE OF LEGITIMATE EXPECTATIONS AND PROTECTION OF TRUST
}

\begin{abstract}
Summary
This paper is an attempt to approach the principle of legitimate expectations and protection of trust from the perspective of institutional trust. The main question concerns the meaning of the term 'trust' as used in the Code of Administrative Procedure and the Tax Law. The further concern is whether institutional trust is at all conceptually possible. An affirmative answer to that requires adding the 'placing a bet' or an 'interest perspective' regarding the trusting person to the definition of 'trust'. The absence of that ingredient leads to a conclusion that the term 'trust' as used in article 121 of the Tax Law and article 8 of the Code of Administrative Procedure would merely denote relying on the organ of administration rather than having trust in it. Understanding the term 'trust' enables one to establish that the trust in public organs of administration is of pragmatic and moral nature.
\end{abstract}

\footnotetext{
58 Teoretycznie odpowiedzi mogą wskazywać na to, że racjonalna będzie postawa zaufania, postawa nieufności albo postawa, która z punktu widzenia zaufania jest irrelewantna.

${ }^{59}$ P. Sztompka, op. cit., s. 341.
} 
